\title{
Lease or easement for a forest plot for linear objects: an economic aspect
}

\author{
Olga Mezenina ${ }^{1, *}$, Anna Mihailova ${ }^{1}$, Margarita Kuzmina $^{1}$, and Olga Zueva ${ }^{1}$ \\ ${ }^{1}$ Ural state forest engineering university, 37, Siberian tract, 620100, Ekaterinburg, Russia
}

\begin{abstract}
In this article, we will consider the interesting, in our opinion, presented data of practitioners and scientists in terms of the study of more cost-effective disposal of forest plots provided for linear objects on the lands of the forest fund of Russia. In our opinion, today it is quite relevant to resolve issues around the payment for the use of forest plots for linear objects for our country: granting the right to lease or establish an easement for the considered plots, as well as conducting forecast financial calculations of these options for the provision of land for 2020. In this article, we only showed forward-looking calculations on the example of the Ural Federal District, which has almost $10 \%$ of the country's forest land (almost $60 \%$ of the district's area), for conclusions about the damage to the budget due to lost revenue due to the choice of the form of granting forest plots, a more complete study of the economic mechanism of land management of the country is necessary, such a task the authors have not yet set themselves.
\end{abstract}

\section{Introduction}

First, we will present the conditions for the use of forest plots and massifs for the construction, reconstruction, and operation of linear objects (Fig.1), where the Forest Code of the Russian Federation notes-forest fund lands are provided to citizens and legal entities:

1) in permanent (perpetual) use of the public authorities and local governments; state and municipal institutions (budget, Treasury, independent); state enterprises; the centers of historical heritage of presidents of the Russian Federation ceased to carry out its powers (clause 3 of article 45, paragraph 1. article 9 of the Forestry code and paragraph 2, article 39.9. Land code) indefinitely.

2) a lease agreement (clause 3 of Article 45, clause 1. of Article 9 of the Forest Code) is concluded for a forest plot for a period of up to 49 years (clause 3 of Article 72 of the Forest Code).

3 ) on the right of limited use of someone else's forest land (easement, public easement) (section 3 of article 45, paragraph 1. article 9 of the Forest code, Chapter V. 3, V. 7. Land code) for the construction period, period of operation.

\footnotetext{
*Corresponding author: mob.61@mail.ru
} 


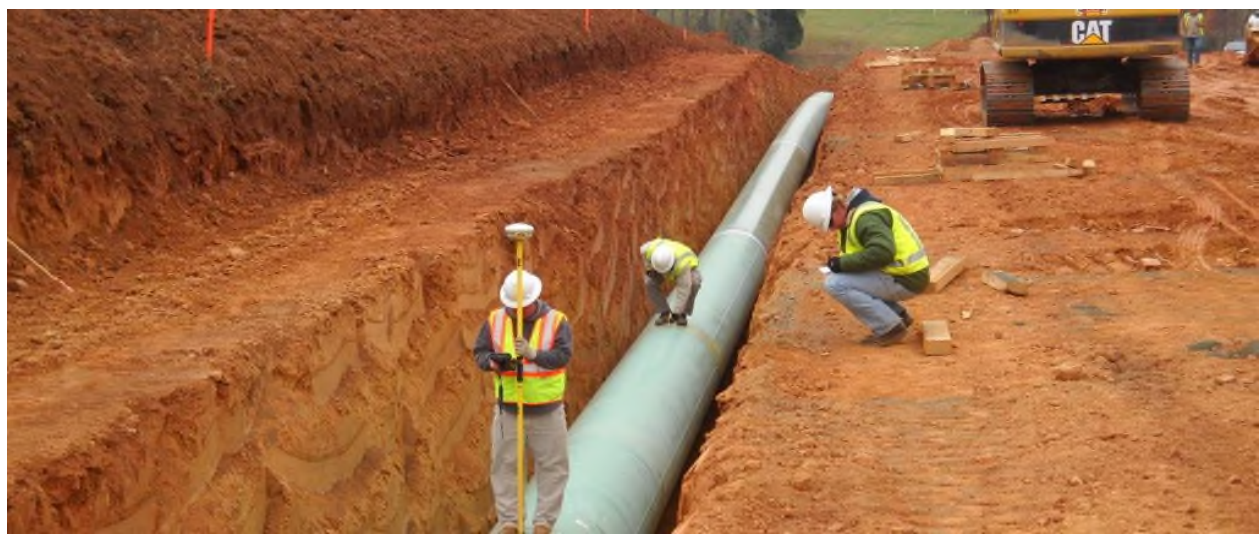

Fig. 1. Laying of linear objects (gas pipeline, power transmission lines, etc.).

To improve the regulatory framework for the establishment of easements for the construction and operation of linear structures, there are objective prerequisites that the current legislation provides for: The legislation does not pay enough attention. The main reason for this situation is the specific nature of such real estate as linear objects, which are characterized by indivisibility and complexity $[1,2]$.

One of the most important practical issues is the justification for the need for an easement. If an easement is still necessary, it should be installed with minimal encumbrance for the land plot on which it is installed. In article 23 of the Land Code of the Russian Federation, it is possible to define the criteria for the least burdensome public easement by setting restrictions on the construction of linear objects on lands of water and forest funds, agricultural purposes, territories with a special protection regime, as well as on reserve lands. The main reason for making a decision on the establishment of an easement - there should be no other options $[3,4,5,6,7,8,9]$.

The institution of easement was introduced into the system of forest and forest land use relatively recently, and therefore, for example, no easement agreements have been concluded for forest plots for linear objects located within the borders of the Khanty-Mansi Autonomous Okrug-Yugra and are the property of the Russian Federation. The paper presents an analysis of the forecast indicators of the amount of possible lost income of the Russian Federation for 2020 when concluding easement agreements with enterprises of the fuel and energy complex.

\section{Basic provisions and methods}

In our work, we want to present judgments about the assessment of easements of linear objects, which is quite an important issue for such a characteristic as the amount of the fee under the agreement for the easement in comparison with the fee under the lease agreement $[3,4,5,7,8,10]$.

The main difference between a lease and an easement.

Lease-a transaction concluded between two parties, one of which grants the use of the land belonging to it (the lessor) to the other party (the lessee). The main condition is the mandatory targeted use of land $[4,5,10]$.

An easement grants the right of limited use of property belonging to another person or state $[3,4,6]$. This right is legally enshrined in article 274 of the Civil Code and in article 23 of the Land Code.

The essential difference between a lease and an easement is their relation to the three main powers: possession, disposal, and use. When an encumbrance is introduced, only one 
of the rights is transferred - use, the rest remain with the owner. When making the rental relationship, the lessee acquires the two powers - the use and ownership. Only the order is the prerogative of the owner of the land plot.

Theoretically, there are still differences:

1. The establishment of an encumbrance is possible by force, when one of the parties does not express any voluntary desire. Lease relations are always concluded on the terms of mutual consent. The rights of the lessor for the duration of the concluded lease agreement are limited. Ownership of the land for this period is granted to the tenant. When an encumbrance is imposed, the rights of the owner of the land territory remain with the owner, the easement receives only a limited right of use. The lease agreement is an urgent document. The possibility of its termination must be recorded in it as one of the conditions. The encumbrance can be permanent or urgent, and its termination occurs only in accordance with the Civil Code: when a separate agreement is concluded or when the case is referred to the court.

2. The charge for the introduction of encumbrances is a payment for compensation for the inconvenience caused, it is always insignificant. You cannot profit from setting a limit. The rent makes it possible to make a profit.

Payment under the agreement on the establishment of an easement in respect of forest plots from the forest fund lands is determined in accordance with the procedure established by the Government of the Russian Federation.

According to paragraph 1 of Article 88 of the Forest Code, persons to whom forest plots are granted for permanent (indefinite) use or lease, as well as persons using forests on the basis of an easement or a public easement established for the purposes provided for in Article 39.37 of the Land Code, make a "Forest Development Project" in accordance with Article 12 of the Forest Code, which does not create a special difference in the procedure and time of creating a document flow in preparation for the transfer of a forest plot for linear objects.

In Russia, 01.09.2018 came into force the Federal law of 03.08.2018 N 341-FZ "On amendments to the Land code of the Russian Federation and certain legislative acts of the Russian Federation to facilitate the placement of linear objects," which pointed the designs of forest land, what made us reflect on the forecast of the financial revenues of the country.

"Legal persons, right of ownership, economic management or the right of operational management to the facilities in accordance with the Land code of the Russian Federation can be accommodated on the land and (or) lands on the basis of a public easement arose in the order established by the legislation of the Russian Federation, to September 1, 2018 and who lack rights to the land on which such buildings shall be entitled to issue a public easement in the procedure provided for in Chapter V. 7 Land code of the Russian Federation, to accommodate such facilities or to acquire the relevant land lease until January 1, 2022."

For calculation of lease payments for the use of plots used in rate per unit area of forest land under Federal ownership, the construction, reconstruction and operation of linear features that are specified in the Decree of the RF Government dated 22.05.2007 N 310 (edited on 06.01.2020).

In accordance with the Land Code of the Russian Federation, the owner of a public easement is obliged to pay a fee for a public easement, unless otherwise provided by law.

The fee for the public easement is calculated in proportion to the area of the forest plot within the established boundaries of the public easement.

The fee charged for the easement includes the following components:

- the equivalent of the actual damage caused without the one that is associated with the need to terminate obligations to third parties ahead of time;

- lost profits, other than those caused by the above-mentioned reason; 
- losses caused to the owner of the land plot due to the early termination of the performance of obligations $[2,4,5,8,10,11]$.

The fee for a public easement in respect of a forest plot is set at 0.01 percent of the cadastral value of such a plot for each year of use. If the land cadastral value is not defined, the fee for a public easement is calculated based on the average cadastral value of land in the municipal area.

The calculation of income on the payment for the use of forests located on the lands of the forest fund, in terms of the minimum amount of payment under the forest plot lease agreement for 2020 (construction, reconstruction, operation of linear objects) is calculated according to the formula 1 :

$$
\text { Д}_{1}=\mathrm{C}_{\mathrm{T}} \times \mathrm{S}
$$

where

$\mathrm{C}_{\mathrm{T}}$ - The average minimum rate of payment per unit area of a forest plot under federal ownership under lease agreements (construction, reconstruction, operation of linear objects), RUB.;

S - $50 \%$ of the average annual area (10,000 ha.) of newly concluded federal-owned contracts for the construction, reconstruction, and operation of linear facilities, ha;

$Д_{1}$ - payment for the use of forests under lease agreements (construction, reconstruction, operation of linear objects), rub.

The calculation of income on the payment for the public easement for 2020 (construction, reconstruction, operation of linear objects) is calculated according to the formula 2:

$$
\mathrm{D}_{2}=\mathrm{S} \times\left(\mathrm{C}_{\mathrm{K}} \times 0,01\right)
$$

where

S - $50 \%$ of the average annual area (10,000 ha) of newly concluded federal-owned land plots for the construction, reconstruction, and operation of linear facilities (ha);

$\mathrm{C}_{\mathrm{K}}$ - the average cadastral value of 1 ha for the subject (rub.);

0,01 - the percentage of the cadastral value of the land plot;

$\mathrm{D}_{2}$ - earnings forecast for the year 2020 for the public easement (RUB).

\section{Results, discussion of the study}

In our study, we will present forecast indicators on the possible volumes of federal budget revenues for 2020 due to the entry into force of norms No. 341-FZ regarding the right of limited use of someone else's land (forest) plot (easement, public easement) when used for the construction, reconstruction, and operation of linear objects in the Ural Federal District (UFD).

According to the lease agreements of forest plots, for which the application of easement norms is possible, concluded before 01.01.2020, a total of 8,152 lease agreements for forest plots for the construction, reconstruction, and operation of linear objects are valid in the Federal District (Fig. 2). 


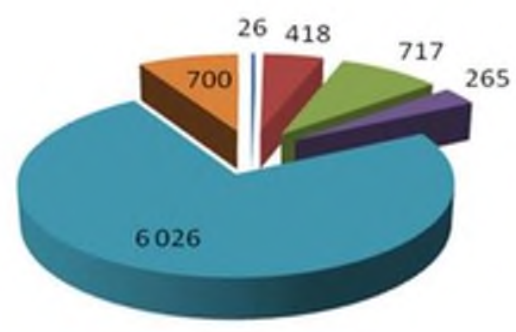

m $\mathrm{Kurgan}$ Oblast

- ' Sverdlovsk Oblast

=' Tyumen Oblast

- Chelyabinsk Oblast

... Khanty-Mansi Autonomous Okrug Yugra

Yamalo-Nenets Autonomous Okrug

Fig. 2. Number of forest land lease agreements concluded for the construction, reconstruction and operation of linear facilities in the Ural Federal District.

According to the diagram, the largest number of existing lease agreements for forest plots for the construction, reconstruction, and operation of linear objects are concluded on the territory of the Khanty-Mansi Autonomous Okrug-Yugra.

In total, in the Federal District in 2020, it is projected that the federal budget will receive rent for the use of forests under lease agreements for forest plots without the use of an easement of 336,036. 4 thousand rubles. (Fig.3)
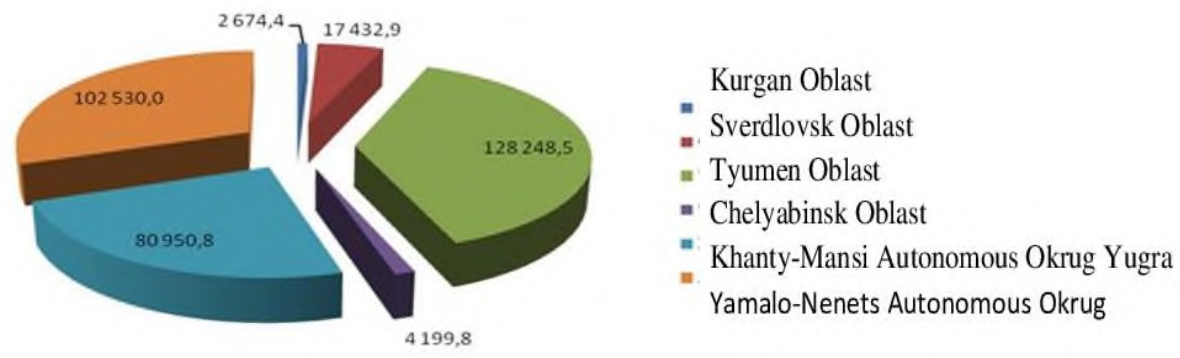

Fig. 3. Forecast of receipt in 2020 of rent for the use of forests under lease agreements for forest plots without the use of an easement in the Ural Federal District, thousand rubles.

In total, in the Ural Federal District, in 2020, it is projected that the federal budget will receive rent for the use of forests under forest land lease agreements, taking into account the application of the easement, 92,691,900 rubles.(Fig.4).

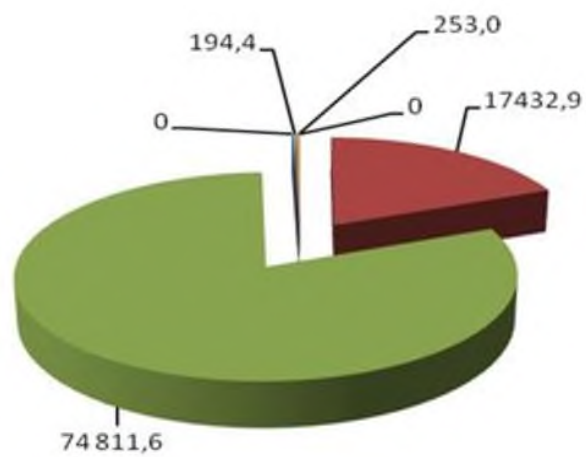

= Kurgan Oblast
$=$ Sverdlovsk Oblast
$=$ Tyumen Oblast
$\equiv$ Chelyabinsk Oblast
= Khanty-Mansi Autonomous Okrug Yugra
E Yamalo-Nenets Autonomous Okrug

Fig. 4. Forecast of receipt in 2020 of rent for the use of forests under lease agreements for forest plots, taking into account the application of the easement in the Ural Federal District, thousand rubles. 
According to the forecast of the falling out of the federal budget revenues, subject to the application of the easement in the Ural Federal District, the amount of the forecast indicators is - 243344.5 thousand rubles. which is $27.6 \%$ (Fig.5).

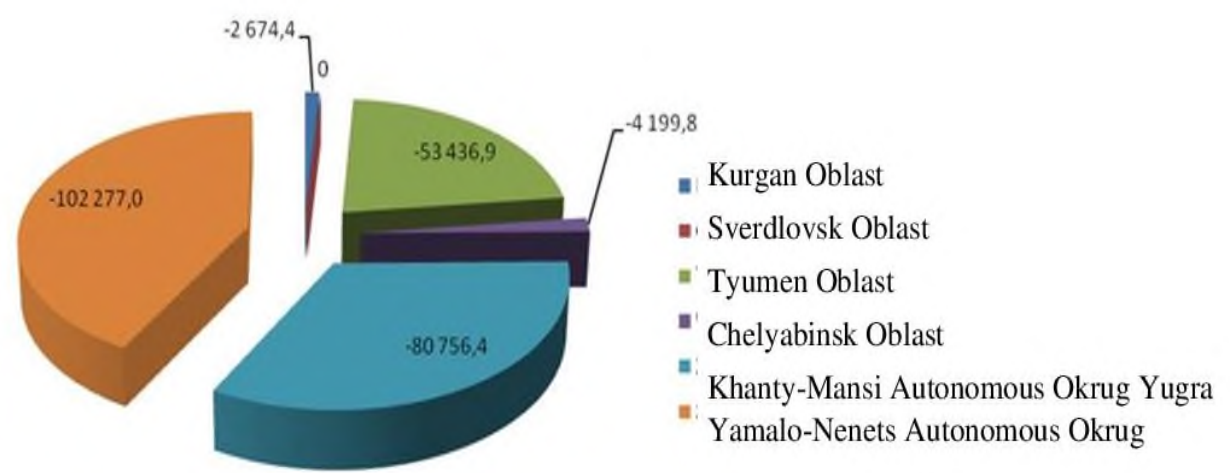

Fig. 5. Forecast of loss of income subject to the application of the easement in the Ural Federal District for 2020.

It is planned to conclude 1,311 agreements in the Ural Federal District under lease agreements for forest plots for which the application of easement norms is possible, which are planned to be concluded in 2020 (Fig.6).
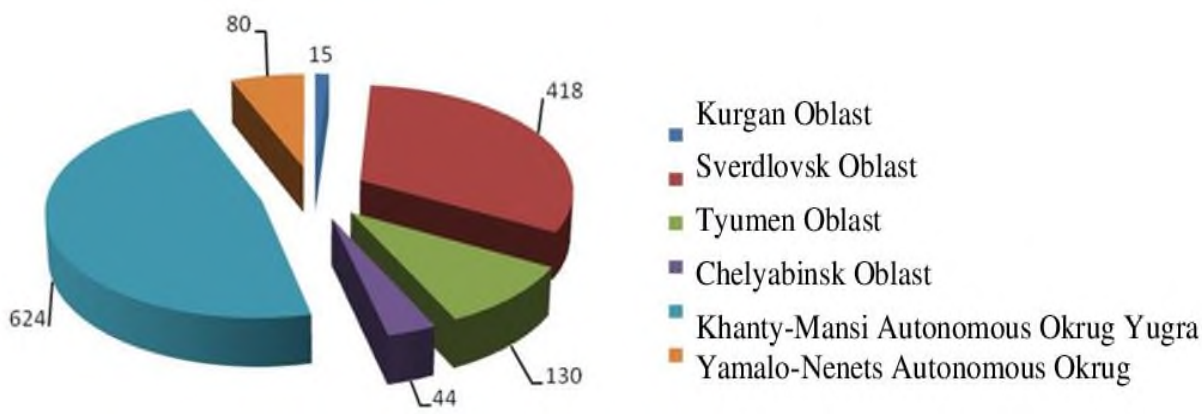

Fig. 6. The number of lease agreements for forest plots planned to be concluded in the Ural Federal District in 2020.

In accordance with the diagram, it is planned to conclude the largest number of existing lease agreements for forest plots for the construction, reconstruction, and operation of linear objects on the territory of the Khanty-Mansi Autonomous Okrug-Yugra.

In total, in the Ural Federal District, in 2020, it is projected that the federal budget will receive rent for the use of forests under the forest land lease agreements planned for conclusion, taking into account without applying the easement, 74,835. 9 thousand rubles (Fig.7). 


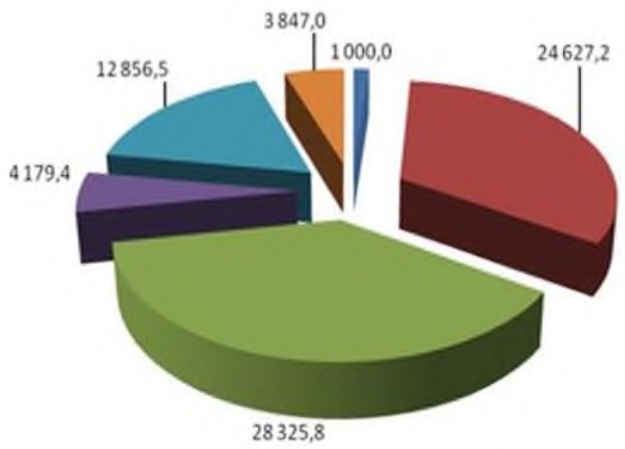

"Kurgan Oblast
" Sverdlovsk Oblast
" Tyumen Oblast
" Chelyabinsk Oblast
" Khanty-Mansi Autonomous Okrug Yugra
Yamalo-Nenets Autonomous Okrug

Fig. 7. Forecast of receipt in 2020 of rent for the use of forests under lease agreements for forest plots planned to be concluded without the application of an easement in the Ural Federal District, thousand rubles.

According to the forecast lost revenues of the Federal budget, provided the use of an easement planned to be concluded in the Ural Federal District the sum of the targets is - (-) 41191 thousand RUB (Fig.8).
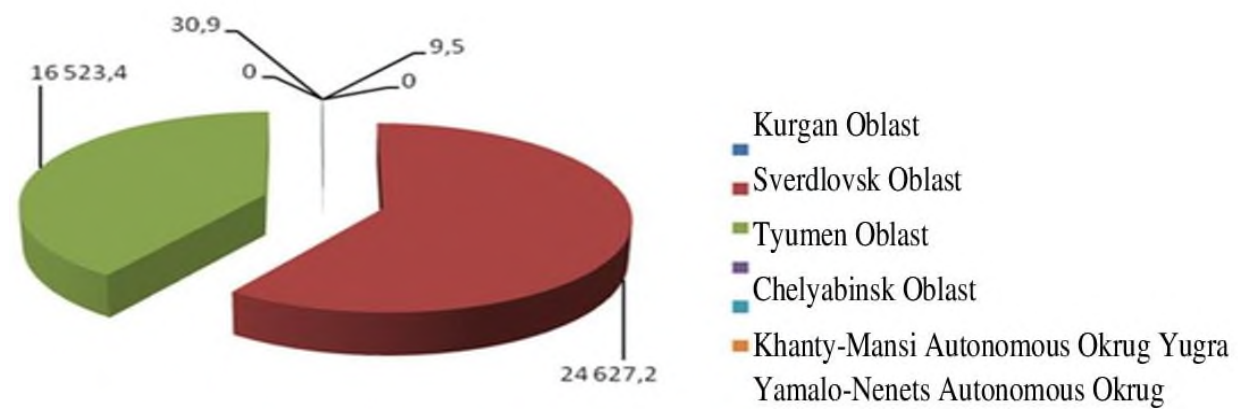

Fig. 8. Forecast of the loss of income subject to the application of the easement for the Ural Federal District for 2020 planned to be concluded.

According to the forecast of falling federal budget revenues, subject to the application of the easement planned for conclusion in the Ural Federal District, the amount of forecast indicators is- ( - ) 33,644,9 thousand rubles, which amounted to 55\% (Fig.9).
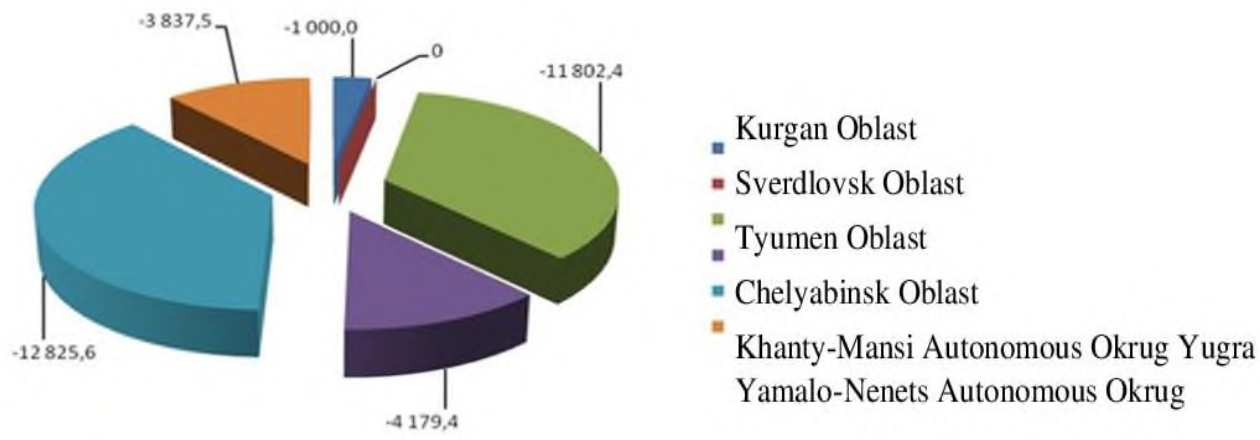

Fig. 9. Forecast of the loss of income subject to the application of the easement for the Ural Federal District for 2020 planned to be concluded. 


\section{Conclusion}

Of course, if you take the position of a land user, it is advisable to conclude easement agreements, where he receives significant savings in payment compared to rental payments for a land plot (the easement fee is less than 30 to 200 times). In the agreement on the establishment of an easement, the essential condition is the remuneration (i.e., reimbursement of the costs of maintaining the site in its original form), and not the amount of the fee, which includes the profit.

But in this study, we have raised this issue on the part of the owner, although probably only on the part of Forestry $[1,4,6,8,10]$.

We do not assume a full understanding of the economic mechanism for solving this issue: rent or easement of a forest plot for linear objects. The owner-state has its own levers and a mechanism for redistributing financial resources of the budget, so the decision to have a lost profit in the registration of forest relations in this case, may well be compensation for a well-thought-out financial scheme, which we have not yet understood.

We believe it is necessary to use a differentiated approach to the determination of objects of forest land in terms of their granting use in the form of rent or the establishment of an easement, according to the goals and objectives of strategic planning of the region's economy and the country as a whole, why make the explanations and amendments to the legislation.

\section{References}

1. F. Riccioli, R. Fratini, E. Marone, C. Fagarazzi, G. Brunialti, Socio-Economic Planning Sciences 100732 (2019) doi: org/10.1016/j.seps.2019.100732

2. B.F. Snydera, L.E. Ruyle, Environmental Science \& Policy 112, 181-188 (2020) doi.org/10.1016/j.envsci.2020.06.020

3. A.R. Rissmana, A.W. Morrisb, A. Kalininc, P.A. Kohlde, D.P. Parkerc, O. Sellesa, Land Use Policy 89, 104221 (2019) doi.org/10.1016/j.landusepol.2019.104221

4. C. Bourguignon, Land Use Policy 33, 100-110 doi.org/10.1016/j.landusepol.2012.11.015

5. Anu Laakkonen, Teppo Hujala, Jouni Pykäläinen, Forest Policy and Economics 99, 157-168 (2018) doi.org/10.1016/j.forpol.2018.07.003

6. A. Juutinena, E. Mäntymaaa, M. Mönkkönenb, R. Sventoa, Forest Policy and Economics 10(4), 230-239 (2008) doi.org/10.1016/j.forpol.2007.10.005

7. K. Krula, P. Ho, Geoforum 110, 46-57 (2020) doi.org/10.1016/j.geoforum.2020.01.015

8. T. Reevesa, B. Meia, J. Sirya, P. Bettingera, S. Ferreirab, Forest Policy and Economics 118, 102241 (2020) doi.org/10.1016/j.forpol.2020.102241

9. Weiyi Zhang, Bin Mei, R.L. Izlar, Forest Policy and Economics 93, 30-35 (2018) doi.org/10.1016/j.forpol.2018.05.008

10. N.M. Bol'shakov, P.N. Zharavin, A.S. Khozyainov, Economy of Region 3(27), 209216 (2011) DOI: 10.17059/2011-3-23

11. A.V. Korotkov, T. Peck, M. Köhl, Encyclopedia of Forest Sciences, 973-982 (2004) doi.org/10.1016/B0-12-145160-7/00158-7 